Milica Mladenović ${ }^{1}$

P. 23-31

Metropolitan University Belgrade,

Faculty of Management

SCIENTIFIC REVIEW PAPER

Bojan Krstić 2

University of Niš, Faculty of Economics

DOI: $10.5937 / E S D 2101023 \mathrm{M}$

Received: August 5, 2020

Accepted: October 18, 2020

\title{
BARRIERS AND MEASUREMENT OF WORK/LIFE BALANCE OF MANAGERS AND OTHER EMPLOYEES
}

\begin{abstract}
Due to major changes and challenges in the way of conducting business in recent decades, establishing work/life balance of employees and managers has become a very important topic. The aim of this paper is to emphasize the obstacles to successfully establishing this balance, the most important of which being the supportive organizational culture and superiors' communication. Another goal of this paper is to introduce the Standards of Excellence Index as a measure for determining the success of the companies' work/life balance programs for employees and managers within 7 components: leadership, strategy, infrastructure, accountability, relationship building, communication, and measurement. In this regard, this paper presents research results on this index in companies in America, where this index was created.
\end{abstract}

Key words: work/life balance, Standards of Excellence Index

JEL classification: 015

\section{ПРЕПРЕКЕ И МЕРЕЊЕ УСКЛАЪЕНОСТИ ПОСЛА И ПРИВАТНОГ ЖИВОТА МЕНАЏЕРА И ОСТАЛИХ ЗАПОСЛЕНИХ}

\begin{abstract}
Апстракт
Због великих промена и изазова у начину пословања у последњим деценијама, усклађивање посла и приватног живота запослених и менацера постало је веома значајна тема. Циь овог рада јесте указивање на препреке успешном успостављању овог баланса, од којих су најзначајније подржавајућа организациона култура и комуникација надређених. Јом један од ијиьева овог рада јесте представљање индекса стандарда изврсности као мерила за утврђивање успешности програма за балансирање живота запослених и менаиера у предузећу у оквиру 7 критеријума: лидерство, стратегија, инфраструктура, одговорност, односи, комуникација и мерење. Са тим у вези, у овом раду су представљени резултати истражсиваға овог индекса у компанијама у Америци, где је овај индекс и настао.
\end{abstract}

Кључне речи: усклађеност посла и приватног живота, индекс стандарда изврсности

\footnotetext{
${ }^{1}$ milica.mladenovic@metropolitan.ac.rs, ORCID ID 0000-0003-3210-0316

2 bojan.krstic@eknfak.ni.ac.rs, ORCID ID 0000-0003-4597-6819
} 


\section{Introduction}

As one of the crucial issues in career development, the concept of work-life balance is based on the idea of spending "a sufficient amount of time" on both work obligations and private life activities (Postolov, Bardarova, Magdinčeva-Sopova, \& Ristovska, 2019). Work/life balance can be achieved by both putting enough "weight" and focus on work activities, and creating a healthy "counterweight" in the form of personal interests and family activities (Mladenović, 2020). In order to establish work/life balance of employees and managers, companies should develop a supportive organizational culture. Superiors' communication on the created work/life balance programs plays a crucial role here. The offered benefits and programs, such as flexible working hours, work from home, or child care (Bird, 2006) should be presented to the employees and managers in a clear and transparent way. Otherwise, there will be no desired increase in employee and management productivity, and consequently no increase in organizational performance, either due to the lack of information on the new benefits, or due to the lack of understanding of the benefits that the offered programs could bring to the employees and managers.

The research conducted on Serbian companies in the service sector has shown a very low level of work/life balance programs and benefits offered to employees and managers (Stojanović-Aleksić \& Bošković, 2017). In addition, offering work/life balance programs does not automatically guarantee their success. On the contrary, the research conducted among UK companies has shown that even after the introduction of work/ life balance programs, employees and managers are often unaware of these benefits that companies offer them or they do not want to use these benefits, for various reasons (Thompson, Beauvais \& Lyness, 1999). Furthermore, research results of American companies have shown that $56 \%$ of employees and managers use work/life balance benefits when offered (Lockwood, 2002). It can be observed that work/life benefits are insufficiently used by both men and women who are focused on developing their careers, but also by single employees and managers who do not have children and family obligations (Kodz, Kersely, Strebler \& O’Regan, 1998).

This paper will address some of the most significant barriers to establishing work/ life balance of employees and managers, as well as introduce the Standards of Excellence Index as a work/life balance measure.

\section{Barriers to establishing work/life balance}

The most common barriers to introducing and using work/life balance programs for employees and managers are the following aspects of organizational culture: fear of negative career consequences, expected working hours, different perceptions of genders, and support from superiors, colleagues, life partners and family members (Reynolds, 1999).

One of the barriers to establishing work/life balance of employees and managers is often the fear of negative career consequences if they use these benefits. Employees and managers are afraid that someone else will take their job if they go on maternity leave or any other type of paid leave - that is exactly why only $3 \%$ of US attorneys use these 
benefits even though $95 \%$ of all US law firms offer various work/life benefits (Kodz, Kersely, Strebler \& O’Regan, 1998).

Superiors often expect their subordinate employees and managers to work a certain number of hours daily, stay overtime and finish part of the work at home, after working hours. This attitude towards work is often perceived as a "sign of commitment, loyalty, productivity, competence and motivation" to get promoted in the company (Reynolds, 1999). These expected working hours are the reason why employees accept additional work obligations and even refuse to go on vacation or take days off, hoping to be perceived as great potential that deserves work promotion (Beauregard \& Lesley, 2008). Companies should understand that overtime work does not indicate a greater work commitment of employees and managers, but rather an inadequate organization or delegation of work tasks. If companies want to help their employees and managers improve their work/life balance, their performance should be evaluated and rewarded based on achieved goals, i.e. results, rather than their working hours. Such a change in organizational culture would encourage employees and managers to value their free time and manage their work and private responsibilities better in order to become more satisfied with their work and private lives.

It is often considered that work/life balance programs are intended exclusively for women, which is supported by the results of a study that has shown that even though work/life imbalance can be observed in both male and female employees, women had a higher level of work/life imbalance (Rose, Hunt \& Ayers, 2007). These different perceptions of genders do not help men. If women are perceived as being in charge of taking care of the children and household, whereas men are considered to be in charge of working and providing better living conditions for their family, the question arises whether men have a real need to use various work/life benefits that would enable them to spend more time with their families. This gender inequality can be resolved by enabling men, not just women, to go on paid leave to take care of their children and family. This would encourage a greater division of responsibilities between men and women, but it would also require the support of the work environment, as well as a change in public opinion and attitudes of the wider community.

One of the most important factors influencing work/life balance of employees and managers is the support from superiors to employees and managers' aspirations and efforts to establish work/life balance. In recent years, superiors have increasingly come to realize that the quality of private life significantly affects the commitment and behavior of employees and managers at work, which has become a good reason for them to support various work/life balance programs in companies, given that work performance of employees and managers ultimately affects company's performance (Nosak \& Zubanov, 2013). Support from superiors essentially represents the following "offer": employees and managers are required to provide the greatest possible contribution and energy at work in exchange for interesting work activities, respectful treatment, opportunities for development and training, as well as a working environment that recognizes and enables the company to adapt to individual needs and obligations of each individual employee and manager (Moore, 2007). It is important to take into account whether superiors really understand the impact of work/life (im)balance of employees and managers on their behavior and work engagement, as well as whether superiors sincerely support the implementation of work/ life balance programs that would be offered to employees and managers. 
Apart from the support from their superiors, the implementation of work/life balance programs for employees and managers can also be affected by the support from their colleagues. It is also not uncommon for colleagues to consider employees who use work/life balance programs as less committed, as if they did not deserve a salary increase or work promotion (Beauregard \& Lesley, 2008).

In addition to the support from superiors and colleagues, support from their life partner also has a significant impact on employees and managers. Partner support is more important in situations in which superiors do not provide support to employees and managers because they do not understand the need for establishing work/life balance. In contrast, for employees and managers who do not receive support from their partners, understanding shown by their superiors reduces their stress levels and leads to greater life satisfaction (Adams, King \& King, 1996). This way, one source of support can in some way compensate for the lack of another. The best situation is, of course, having both support from their superiors as well as partner support, which can lead to even greater life satisfaction of employees and managers.

Partner support can be extended to also include support from family members, which can also lead to greater life satisfaction and work/life balance of employees and managers (Adams, King \& King, 1996).

Only if employees and managers are satisfied in both their work and private lives, will they be able to give their maximum in effort, commitment and energy. Superiors should also encourage employees and managers to use the benefits offered, emphasizing that all people have the need to socialize and improve various aspects of their private lives. By changing the organizational culture and supporting such attitudes, one can expect an increase in overall life satisfaction of employees and managers, and consequently an increase in productivity and performance of the company (Lazăr, Osoian \& Raţiu, 2010).

\section{Standards of excellence index as a measure of work/life balance}

The Standards of Excellence Index is a modern performance measure that enables companies to assess the existing organizational culture in terms of the level and quality of the implemented work/life balance programs for employees and managers (Harrington \& James, 2005). This assessment begins with a survey of employees and managers on the support of organizational culture towards their work and private goals. The Standards of Excellence Index includes 7 components: leadership, strategy, infrastructure, accountability, relationship building, communication, and measurement (Harrington \& James, 2005).

1) Leadership - The Standards of Excellence Index was created to assess the "extent to which leaders understand, support and communicate the importance of work/life balance" of employees and managers (Friedman \& Lobel, 2003). The evaluation of the leadership component is obtained by asking respondents to assess the extent to which leaders are committed to developing an organizational culture that supports work/life balance of employees and managers.

2) Strategy - The strategy for establishing work/life balance of employees and managers should be aligned with the vision, goals, and priorities of the company 
(Bailyn, Fletcher \& Kolb, 1997). In addition, this strategy should address potential barriers to achieving work/life balance.

3) Infrastructure - The company should support the strategy for establishing work/life balance through appropriate infrastructure - by providing the necessary financial, technological and human resources, creating and implementing adequate policies and procedures, as well as by organizing training for employees and managers regarding the implementation of these policies (Harrington \& James, 2005).

4) Accountability - The success of establishing work/life balance is a joint responsibility of superiors, employees and managers. Superiors must balance between the company's business goals on the one hand, and career and private goals of employees and managers on the other hand. Moreover, employees and managers must understand their role and responsibility in achieving the company's goals, but also in implementing work/life balance programs.

5) Relationship Building - The company should promote the organizational culture built on mutually respectful relationships with its employees, managers and other stakeholders (Mirvis, Pitt-Catsouphes, Lewis \& Lichtfield, 1997). Furthermore, the company should strive to gain trust and support of all stakeholders - employees, managers, customers, investors, and the community through active engagement and agreement.

6) Communication - The strategy for establishing work/life balance of employees and managers should be constantly promoted in the company's internal communication. This can improve understanding of work tasks, increase motivation and provide feedback on the performance and social needs of employees and managers (Bailyn, Fletcher \& Kolb, 1997). Employees often do not express their work/life balance needs out of fear of not seeming committed enough to the company or not being offered a work promotion, which leads to nervousness and reduced satisfaction, productivity, and retention of employees and managers (Bailyn, Fletcher \& Kolb, 1997). In order to prevent these negative consequences, it is important that the company understand the needs of its employees and managers, and adequately communicate the strategy for establishing work/life balance throughout the company.

7) Measurement - The company should strive to constantly improve work/ life balance of its employees and managers through constant assessment and measurement of the implementation of its work/life balance strategy. It is important to assess the company's "general health in terms of productivity, satisfaction, retention, and utilization of various work/life benefits" of employees and managers (Harrington \& James, 2005). This way, measurement enables the perception of the company's strengths and weaknesses, as well as the comparison of the implemented benefits in the company with other companies.

The Standards of Excellence Index enables measurement of the company's efforts to establish work/life balance of its employees and managers by "dividing organizational performance into smaller components and focusing on tangible measures" (Harrington 
\& James, 2005). Measuring the success of the implementation of the strategy for establishing work/life balance of employees and managers can help justify spending resources for the implementation of this strategy.

Table 1: Some of the statements that are assessed in the company for all 7 components of the Standards of Excellence Index

\section{1) Leadership:}

1.1. Leaders create an organizational culture that values work/life balance as a component of organizational identity.

1.2. Through their behavior, leaders create an environment supportive of establishing work/life balance.

\section{2) Strategy:}

2.1. The company has a strategic plan for establishing work/life balance of employees and managers.

2.2. The company creates long-term work/life balance programs and benefits.

\section{3) Infrastructure:}

3.1. Leaders are trained on implementing work/life balance strategies and helping employees and managers resolve work/life balance issues and conflicts.

3.2. Sufficient financial and human resources are allocated for work/life balance programs.

\section{4) Accountability:}

4.1. Leaders are responsible for balancing company's business goals with employees and managers' work/life balance needs.

4.2. Leaders are responsible for implementing work/life balance programs and encouraging employees and managers to use them.

\section{5) Relationship Building:}

5.1. Work/life balance professionals work with employees and managers in the company to integrate work/life balance into its organizational culture.

5.2. The company collaborates with work/life balance professional organizations to provide efficient work/life balance solutions for its employees and managers (e.g. child care, elderly care, work/life balance associations...).

\section{6) Communication:}

6.1. Leaders identify important work/life balance issues by communicating to the company's employees and managers.

6.2. The company communicates and educates its employees and managers on available work/life balance programs and benefits.

\section{7) Measurement:}

7.1. The company monitors the use of its work/life balance programs.

7.2. The company monitors the effect of its work/life balance programs on its performance measures (e.g. productivity, work efficiency, quality of work, work satisfaction...).

Source: Adapted from: Harrington, B., \& James, J. B. (2005). The Standards of Excellence in Work/Life Integration: From Changing Policies to Changing Organizations. In Pitt-Catsouphes, M., Kossek, E., \& Sweet, S. The Work and Family Handbook: MultiDisciplinary Perspectives, Methods and Approaches (pp. 665-683). Mahwah, NJ: Lawrence Erlbaum Associates. 
Representatives of human resources sectors of the most successful US multinational companies were invited to assess their companies regarding the 7 components of the Standards of Excellence Index (Harrington \& James, 2005). These ratings were then used to create a US national database, which can be used to compare companies by the success of the implementation of strategies for establishing work/life balance of employees and managers. However, this assessment of companies is based on subjective opinions of HR representatives, so the evaluation was limited by their knowledge, experience, and perceptions of the company.

For each of the 7 components of the Standards of Excellence Index, specific statements are defined, and the degree of their implementation and existence in the company is assessed using the Likert scale, from grade 1 - "not at all" to grade 5 - "to a large extent" (Table 1). All grades for each of the 7 components are then summed up, and an average grade for each individual component is calculated, representing the overall success of their implementation in the company. The maximum total score for each component can be 100 .

\section{Figure 1: Average grades for 7 components of the Standards of Excellence Index from} the US national database

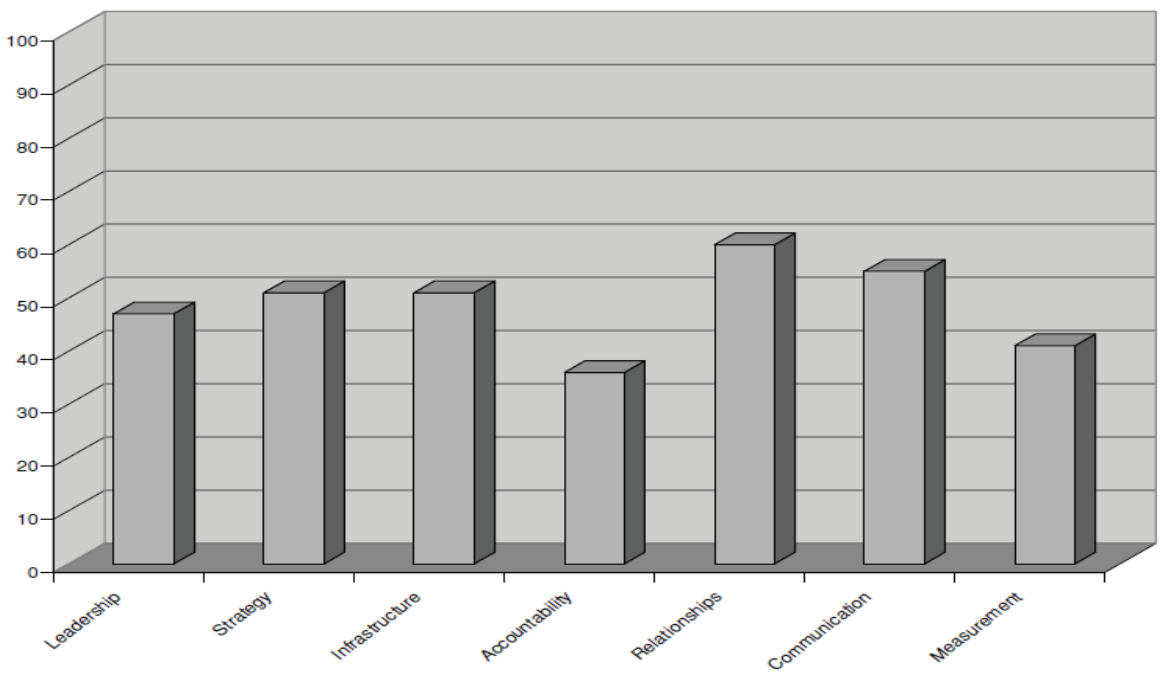

Source: Harrington, B., \& James, J. B. (2005). The Standards of Excellence in Work/ Life Integration: From Changing Policies to Changing Organizations. In PittCatsouphes, M., Kossek, E., \& Sweet, S. The Work and Family Handbook: MultiDisciplinary Perspectives, Methods and Approaches (pp. 665-683). Mahwah, NJ: Lawrence Erlbaum Associates.

Figure 1 shows average grades for 7 components of the Standards of Excellence Index from the US national database, revealing certain strengths and weaknesses of American companies. The components with the highest average grades are relationship building (average grade 60) and communication (average grade 54.7), which shows that the greatest progress in American companies has been made in these areas. The components with satisfactory implementation in companies, with room for improvement, are strategy (average grade 50.8) 
and infrastructure (average grade 50.5). The components with the lowest average grades are leadership (46.5), measurement (40.6) and accountability (35.5). Respondents feel not only that superiors do not provide enough support to employees and managers in establishing work/ life balance, but also that they are not held accountable for the implementation of work/life balance programs or for balancing between the company's business goals and employees and managers' private goals. Respondents also have the impression that many measurement-related issues have not been given enough attention in companies (many work/life balance factors are still not measured and monitored). Low measurement grades indicate companies' failure to link work/life balance programs to employees and managers' performance. All this indicates significant weaknesses of companies, which need to be addressed and improved in the future.

It should be noted that the Standards of Excellence Index was primarily created as a tool for companies' self-assessment, learning and improvement, rather than as a tool for ranking or rewarding companies (Harrington \& James, 2005). In other words, this index serves companies in assessing the success of their efforts and programs for establishing work/life balance of their employees and managers, as well as in planning future programs and activities to support employees and managers in balancing their work and private lives. The Standards of Excellence Index can therefore indicate both "strengths (areas of excellence) and weaknesses (areas for improvement)" of the company, enabling the company to identify priorities, i.e. the most critical areas for improvement that should be addressed first. It can be concluded that the Standards of Excellence Index shows the extent to which companies have integrated work/life balance programs for employees and managers into their human resource management strategies, but also the extent to which these programs are practically implemented in their everyday business.

\section{Conclusion}

In today's way of conducting business, establishing work/life balance has been gaining more and more importance. There are some barriers to that, specifically the lack of support of the organizational culture. Developing an organizational culture that supports establishing work/life balance of employees and managers involves changing the way that both superiors and managers think about their work and work/life balance, with the aim of making work/life benefits acceptable for everyone, regardless of gender, age, years of work in the company, or private obligations. As a means of measuring work/life balance in a company, the Standards of Excellence was created and introduced in American companies, which is presented in detail in this paper.

\section{References}

Adams, A. G., King, A. L., \& King, W. D. (1996). Relationships of Job and Family Involvement, Family Social Support and Work/Family Conflict with Job and Life Satisfaction. Journal of Applied Psychology, 81(4), 411-420.

Bailyn, L., Fletcher, J. K., \& Kolb, D. (1997). Unexpected Connections: Considering Employees' Personal Lives Can Revitalize Your Business. Sloan Management Review, 38(4), 11-19. 
Beauregard, A., \& Lesley, C. H. (2009). Making the Link between Work/Life Balance Practices and Organizational Performance. Human Resource Management Review, 19(1), 9-22.

Bird, J. (2006). Work/Life Balance - Doing It Right and Avoiding the Pitfalls. Employment Relations Today, 33(3), 21-30.

Friedman, S. D., \& Lobel, S. (2003). The Happy Workaholics. Academy of Management Executives, 17(3), 87-98.

Harrington, B., \& James, J. B. (2005). The Standards of Excellence in Work/Life Integration: From Changing Policies to Changing Organizations. In PittCatsouphes, M., Kossek, E., \& Sweet, S. The Work and Family Handbook: MultiDisciplinary Perspectives, Methods and Approaches (pp. 665-683). Mahwah, NJ: Lawrence Erlbaum Associates.

Kodz, J., Kersley, B., \& Strebler, M. T. (1998). Breaking the Long Hours Culture - IES report 352. Institute for Employment Studies.

Lazăr, I., Osoian, C., \& Raţiu, P. (2010). The Role of Work/Life Balance Practices in Order to Improve Organizational Performance. European Research Studies, 13(1), 201-214.

Lockwood, N. R. (2002). Use of Work/Life Benefits on the Rise. IOMA's Report on Managing Benefits Plans, 2(8), 7-9.

Mirvis, P., Pitt-Catsouphes, M., Lewis, S., \& Litchfield, L. (1997). Participation in Change: Work/Family Groups in Corporations. Work/Family Policy Paper Series.

Mladenović, M. (2020). Ravnoteža između poslovnog i privatnog života zaposlenih i menadžera - pogodnosti za balansiranje života i njihovi efekti. Ekonomski izazovi, 9(17), 67-79.

Moore, F. (2007). Work/Life Balance: Contrasting Managers and Workers in a Multinational Company. Employee Relations, 29(4), 385-399.

Nosak, T., \& Zubanov, V. (2013). Harmonizacija poslovnih i privatnih ciljeva zaposlenih. TIMS Acta, 7(2), 77-85.

Postolov, K., Bardarova, S., Magdinčeva-Sopova, M., \& Ristovska, A. (2019). Challenges in Managing Your Own Career Development, Ekonomski pogledi, 21(1), 17-34.

Reynolds, H. B. (1999). Work/Life Initiatives Require Cultural Readiness. Employee Benefit Plan Review, 54(6), 25-26.

Rose, S., Hunt, T., \& Ayers, B. (2007). Adjust the Balance: Literature Review Life Cycles and Work Life Balance, Centre for Health Psychology, Staffordshire University

Stojanović-Aleksić, V., \& Bošković, A. (2017). Društvena odgovornost preduzeća i etičko liderstvo. Ekonomika održivog razvoja, 1(2), 71-84.

Thompson, C. A., Beauvais, L. L., \& Lyness, K. S. (1999). When Work/Family Benefits Are not Enough: The Influence of Work/Family Culture on Benefit Utilization, Organizational Attachment and Work/Family Conflict. Journal of Vocational Behavior, 54, 392-415. 